\title{
Weights of Lysimachea from the Tekirdağ Museum and Various Collections
}

\section{Oğuz Tekin}

\section{(2) OpenEdition \\ 1 Journals}

Electronic version

URL: http://journals.openedition.org/anatoliaantiqua/294

DOI: 10.4000/anatoliaantiqua.294

\section{Publisher}

IFEA

\section{Printed version}

Date of publication: 1 January 2014

Number of pages: 145-153

ISBN: 9782362450136

ISSN: 1018-1946

\section{Electronic reference}

Oğuz Tekin, «Weights of Lysimachea from the Tekirdağ Museum and Various Collections », Anatolia Antiqua [Online], XXII | 2014, Online since 30 June 2018, connection on 18 December 2020. URL http://journals.openedition.org/anatoliaantiqua/294; DOI : https://doi.org/10.4000/anatoliaantiqua 294 


\section{ANATOLIA ANTIQUA ESKI ANADOLU}

\section{XXII}

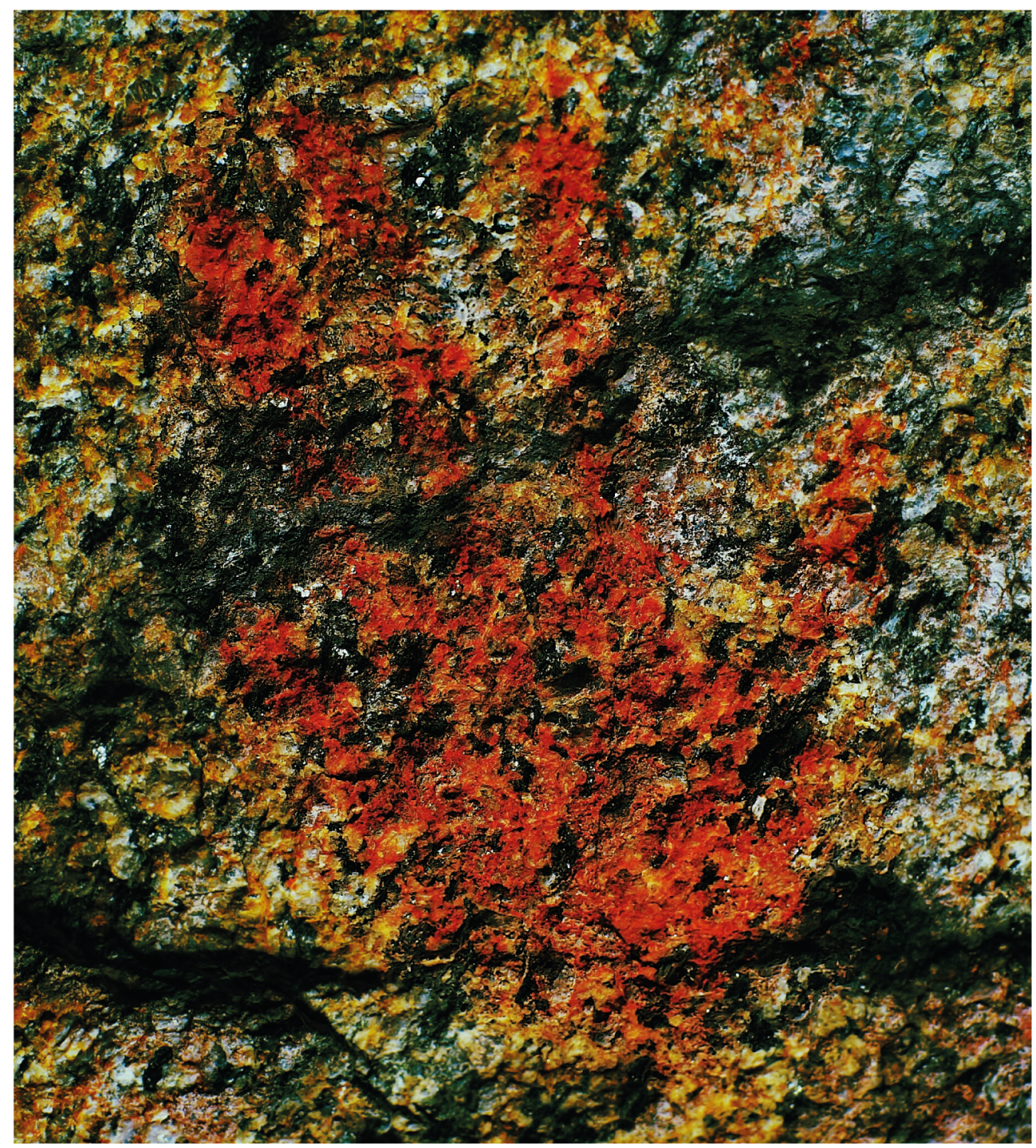

INSTITUT FRANÇAIS D'ETUDES ANATOLIENNES GEORGES-DUMEZIL CNRS USR 3131

DE BOCCARD 


\section{TABLE DES MATIERES}

Emma BAYSAL,

A preliminary typology for beads from the Neolithic and Chalcolithic levels of Barcın Höyük

William ANDERSON, Jessie BIRKETT-REES, Michelle NEGUS CLEARY,

Damjan KRSMANOVIC et Nikoloz TSKVITINIDZE,

Archaeological survey in the South Caucasus (Samtskhe-Javakheti, Georgia):

Approaches, methods and first results

Eda GÜNGÖR ALPER,

Hellenistic and Roman period ceramic finds from the Balatlar Church excavations in

Sinop between 2010-2012

Ergün LAFLI et Gülseren KAN ŞAHİN,

Hellenistic ceramics from Southwestern Paphlagonia

Oğuz TEKIN,

Weights of Lysimachea from the Tekirdağ Museum and various collections

Oğuz TEKIN,

Three weights of Lampsacus

Julie DALAISON et Fabrice DELRIEUX,

La cité de Néapolis-Néoclaudiopolis : histoire et pratiques monétaires

Martine ASSENAT et Antoine PEREZ,

Amida 4. Constance II et Amida

Sencan ALTINOLUK et Nilüfer ATAKAN,

Abrasax: A magical gem in the Istanbul Archaeological Museums

Bahadır DUMAN,

A group of local production Middle Byzantine period pottery from Tripolis:

'Micaceous White Painted Ware'

CHRONIQUES DES TRAVAUX ARCHEOLOGIQUES EN TURQUIE, 2014

Jean-Charles MORETTI,

avec la collaboration de Nicolas BRESCH, Isabel BONORA, Jean-Jacques MALMARY et

Olivier RISS,

Claros, le Temple d'Apollon : travaux réalisés en 2013

Suat ATEŞLIER,

On the excavations of the Zeus Temple of Alabanda 
Olivier HENRY,

avec Ayşe Güliz BİLGIN ALTINÖZ, Jesper BLID, Ömür Dünya ÇAKMAKLI, Andrew DUFTON, Agneta FRECCERO, Linda GOSNER, Ragnar HEDLUND, Pascal LEBOUTEILLER,

Vasilica LUNGU, Felipe ROJAS, Fredrik TOBIN, Baptiste VERGNAUD et

Andrew WATERS,

La mission Labraunda 2013 - Rapport préliminaire

Dominique BEYER, Isabelle CHALIER, Françoise KIRNER,

Françoise LAROCHE-TRAUNECKER et Aksel TIBBET,

Zeyve Höyük - Porsuk. Rapport préliminaire sur la campagne 2013

Çiğdem MANER,

Preliminary report on the first season of the Konya-Ereğli (KEYAR) survey 2013 


\section{WEIGHTS OF LYSIMACHEA FROM THE TEKIRDAĞ MUSEUM AND VARIOUS COLLECTIONS}

Lysimachea (modern-day Bolayır) ${ }^{1}$ was a Hellenistic city located in the neck where the Gallipoli peninsula (Thracian Chersonese) joins the European mainland. After the death of Alexander the Great, his enormously vast empire was divided up, and the regions of Thrace and Northwestern Asia Minor fell to Lysimachus. A short time later, in 309 B.C., Lysimachus founded a new city on the Thracian Chersonese (modern-day Gallipoli Peninsula), naming it Lysimachea after himself². Lysimachus settled people from neighbouring cities, especially from Cardia (modern-day Bakla Burnu) ${ }^{3}$, in his new city. Consequently, the lion image that had been in use on Cardia's coins ${ }^{4}$ came to be used on the coins and weights of Lysimachea as well.

Much of Lysimachus' reign was spent fighting against Alexander's other successors as well as against the Odrysian king Seuthes III $^{5}$. Lysimachea, the capital city of his kingdom, was destroyed by an earthquake in 287 B.C. ${ }^{6}$. He was finally killed fighting while losing battle against the Seleucids at Corupedium in 281 B.C. Though the city of Lysimachea continued to develop while under Seleucid control, by the end of the $2^{\text {nd }}$ century B.C. it had fallen into obscurity. In the time of Pliny it was already deserted ${ }^{7}$. The name of Lysimachea was mentioned a last time by Ammianus Marcellinus ${ }^{8}$.

Although it is hard to estimate the number of the Lysimachean weights in the collections, the number of the known examples is about thirty; but the actual number should be naturally more. The Lysimachean weights are recognised relatively easily.

\begin{abstract}
Most of the extant examples are of lead, but there are also rare weights of bronze. On the obverses of the Lysimachean weights is depicted a jumping lion. On the large units (such as mna and its multiples) there is a full figure of lion while on the fractions (such as hemimnaion, tetarton etc.) is only a lion protome. As it is clear from the following examples, a bronze hemimnaion weight bears a full-figured lion, contrary to expectations. The lion was a symbol both of Lysimachus, the founder of Lysimachea, and of the city, highly likely, copied from the Cardian coinage. On the Lysimachean weights, besides the lion, there is an abbreviated ethnic $(\Lambda Y \Sigma I$ or $\Lambda Y$ ), whose letters are placed on each corner. This is an abbreviated form of the ethnic in the genitive ( $\Lambda v \sigma \mu \alpha \chi \varepsilon^{\prime} \omega \nu=$ of Lysimacheans). The reverses of the weights are left blank.

The last decade of the $4^{\text {th }}$ century B.C. is the terminus post quem for the earliest Lysimachean weights since the city was founded in about 309 B.C. The deadline for the Lysimachean weights is about mid$2^{\text {nd }}$ century B.C. when Lysimachea was destroyed by the Thracians. But, even though the attacks of the Thracians destroyed the city dramatically, one may think that the city continued its presence for a while; at least the commercial life was not halted entirely. Consequently, it is possible that the Lysimachean weights may have continued to be produced or used in the second half of the $2^{\text {nd }}$ century B.C. This article deals with sixteen lead weights of Lysimachea, majority from the Tekirdağ Museum and some from various collections, not published previ-
\end{abstract}

\footnotetext{
* Istanbul University, Ancient History Department, Beyazit-İstanbul. E-mail: tekinotekin@yahoo.com

1) Brodersen 1986; Sayar 2007.

2) Strabo: VII frags. 51-52; Diodorus Siculus: XX.29.1.

3) Pausanias: I.9.8.

4) Tzvetkova 2009.

5) For Lysimachus and his activities see Lund 1992.

6) Justinus: XVII.1.

7) Pliny: IV.18.

8) Marcellinus: XXII.8.5.
} 
ously. They are listed below from the large units to small units ${ }^{9}$.

1) Tekirdağ Museum (inv. ${ }^{\circ} 1$, tentative).

Trimnaion (Fig. 1)

This square lead weight with rounded corners measures $80 \times 79 \times 23 \mathrm{~mm}$ and weighs $1400 \mathrm{~g}$; on the upper edge there is a depression (cut); worn. Letters on the corner $(\Lambda-\mathrm{Y}-\Sigma-\mathrm{I})$ are not visible except the one (lambda) on the top left corner and maybe a $\Sigma$ on the bottom left corner. On the obverse, there is a lion jumping right, in relief, but it is hardly visible since it is worn. Below the belly of the lion one may expect a letter indicating the denominational mark, i.e. $\Gamma$, but it is not visible or there is no letter at all. The reverse is blank. Its mass corresponds to a trimnaion (mna of $466.66 \mathrm{~g}$ ). Find place and date: Bolayır, 2013.

2) Tekirdağ Museum (inv. $n^{\circ} 15$, tentative). Mna (Fig. 2)

Lead weight, triangular in form, measuring $85 \times 86 \times 13 \mathrm{~mm}$ and weighing $509 \mathrm{~g}$; there are depressions (cuts) on the face. On the obverse is a lion jumping left, in relief. Above the lion, is a $\Lambda$ ?, i.e. the initial letter for ethnic. Since the obverse is too worn it is difficult to identify the type (or the letter) clearly. The reverse is blank. Its mass corresponds to a mna. Find place and date: Bolayır, 2013.

3) Private coll. (RK 001).

Mna (Fig. 3)

This is a square lead weight measuring $66 \mathrm{x} 65 \mathrm{x}$ $12 \mathrm{~mm}$ and weighing $502.9 \mathrm{~g}$ with slightly rounded corners; worn. On the obverse, a lion jumping right; on each corner, from top left, $\Lambda-Y-\Sigma-\mathrm{I}$; below the belly of the lion, $M$; all in relief. While $\Lambda-Y-\Sigma-$ I stands for $(\Lambda \nu \sigma \mu \alpha \chi \chi \dot{\varepsilon} \omega \nu), M$ stands for $\mu \nu \tilde{\alpha}$. The reverse of the weight is blank. This weight was acquired in Tekirdağ in 1990s or later.

4) Tekirdağ Museum (inv. $n^{\circ} \mathrm{A}$, tentative). Mna (Fig. 4)

This is also a square lead weight measuring $60 \times 59 \times 13 \mathrm{~mm}$ and weighing $501.4 \mathrm{~g}$ with slightly rounded corners; worn; on the obverse there is an iron piece nailed into the weight. On the obverse, a lion jumping right; on each corner, from top left, $\Lambda-Y-\Sigma-I$ which stands for $\Lambda v \sigma \mu \alpha \chi \varepsilon \dot{\varepsilon} \omega v)$; below the belly of the lion (between $\Sigma$ and I), M which stands for $\mu v \tilde{\alpha}$; all in relief. The reverse of the weight is blank. Find place and date: Bolayır, 2013.
5) Private coll. (RK 003).

Hemimnaion (Fig. 5)

A square lead weight which measures $46 x 45 x$ $12 \mathrm{~mm}$ and weighs $248.2 \mathrm{~g}$; worn. On the obverse is a lion protome jumping right, head turned back?; on each corner, from top left, $\Lambda-\mathrm{Y}-\Sigma-\mathrm{I}$; below the belly of the lion (between $\Sigma$ and I), $\mathrm{H}$ which stands

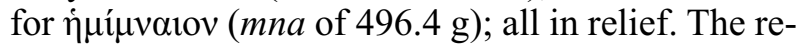
verse of the weight is blank. This weight was acquired in Tekirdağ in 1990s or later.

6) Tekirdağ Museum (inv. $n^{\circ} 3$, tentative).

Hemimnaion (Fig. 6)

A square lead weight measuring 46x46×12 mm and weighing $248 \mathrm{~g}$; with rounded corners; worn. On the obverse is a protome of a lion jumping right; its head is discoid, looking back. On the corners, $\Lambda-[\mathrm{Y}]-\Sigma-\mathrm{I}$; below the belly of the lion is an M-like $\mathrm{H}$ which stands for $\eta \mu$ í $\mu v \alpha 10 v$ (mna of $496 \mathrm{~g}$ ); all in relief. The reverse is blank. Find place and date: Bolayır, 2013.

7) Private coll. (RK 005).

\section{Hemimnaion (Fig. 7)}

A lead weight, rhombus in form with rounded corners; measuring $50 \times 48 \times 13 \mathrm{~mm}$ and weighing $241.2 \mathrm{~g}$; worn. On the obverse is a lion protome jumping right, head turned back; on each corner, from top left, $\Lambda-[\mathrm{Y}]-\Sigma-\mathrm{I}$; below the belly of the

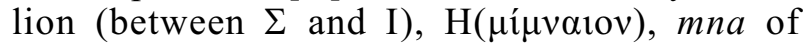
$482.4 \mathrm{~g}$; all in relief. The reverse of the weight is blank. This weight was acquired in Tekirdağ in 1990s or later.

8) Tekirdağ Museum (inv. $n^{\circ} 8$, tentative).

\section{Hemimnaion (Fig. 8)}

This lead weight is square in form with rounded corners and slightly concave edges; it measures $46 \times 47 \times 10 \mathrm{~mm}$ and weighs $232.5 \mathrm{~g}$. On the obverse is a lion protome jumping right, with its head turned back, in relief; on the corners, $\Lambda-[\mathrm{Y}]-\Sigma-\mathrm{I}$ and below the belly of the lion, $\mathrm{H}$ for ' $\eta \mu$ í $\mu v \alpha 10$ ( $m n a$ of 465 $\mathrm{g}$ ); all in relief. The reverse is blank. Find place and date: Bolayır, 2013.

9) Tekirdağ Museum (inv. $n^{\circ} 16$, tentative).

Hemimnaion (Fig. 9)

A lead weight, square in form with rounded corners, measuring 49x48x9 mm and weighing $227.3 \mathrm{~g}$. On the obverse is a lion protome, jumping right, head turned back?; the back part of the animal is worn so it is difficult to be sure whether it is a

9) I would like to thank Önder Öztürk, director of the Tekirdağ Museum and Ahmet Mercan, director of the Karadeniz Ereğli Museum, Izak Eskinazi, the collector, as well as the other collectors who permitted me to publish the weights in their collections. 


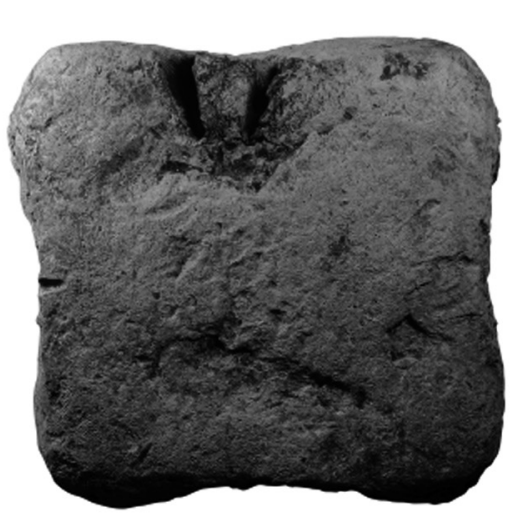

1

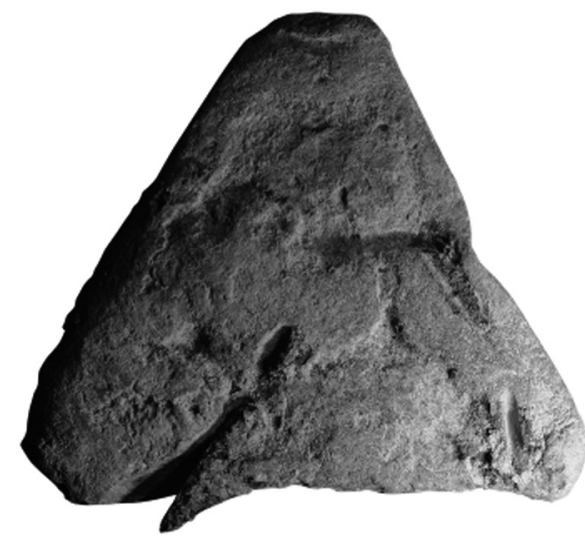

2

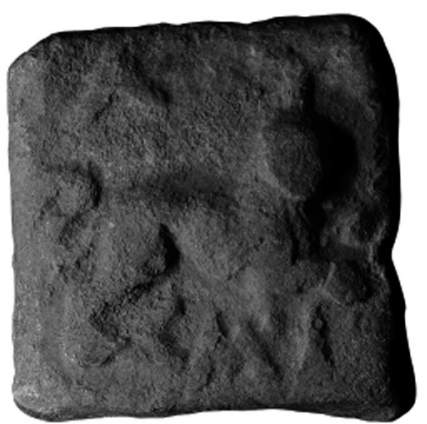

3

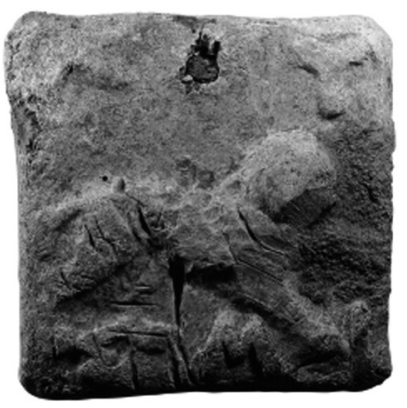

4

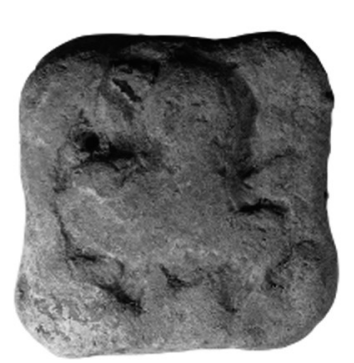

8

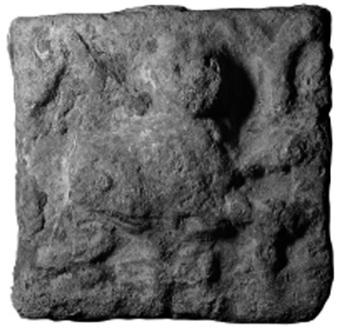

5

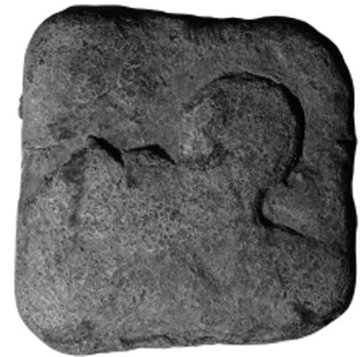

9

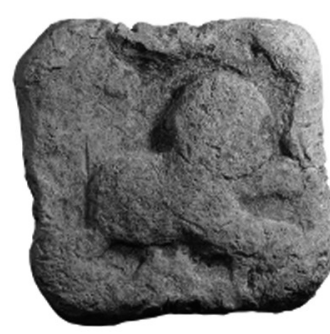

6

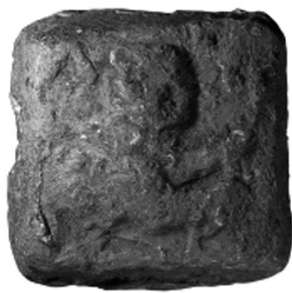

10

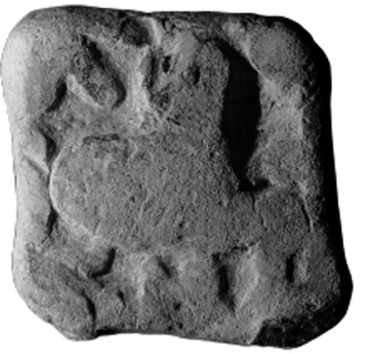

7

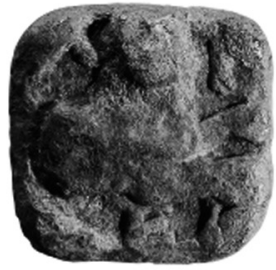

12

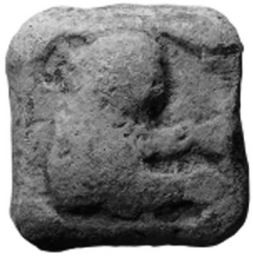

13

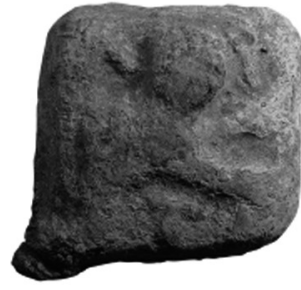

14

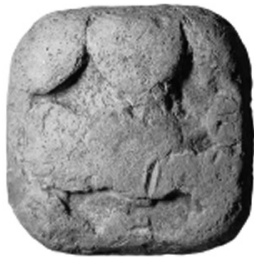

15

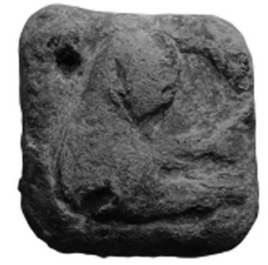

11

1. Tekirdă̆ Museum (1); 2. Tekirdağ Museum (15); 3. Private coll. RK (001); 4. Tekirdă̆ Museum (A); 5. Private coll. RK (003); 6. Tekirdağ Museum (3); 7. Private coll. RK (005); 8. Tekirdă Museum (8); 9. Tekirdağ Museum (16); 10. Private coll. HK (003); 11. Private coll. Eskinazi (17); 12. Karadeniz Ereğli Museum (1989/27); 13. Tekirdağ Museum (B); 14. Tekirdağ Museum (6); 15. Tekirdağ Museum (17); 16. Private coll. HK (004). 
protome or a full figure but hemimnaion weights generally bear protomes; all in relief. The letters at the corners are not visible except the lambda on the top left corner: $\Lambda-[\mathrm{Y}-\Sigma-\mathrm{I}]$. The denominational mark which might be placed below the belly of the lion is not visible or no mark. Its mass corresponds to a hemimnaion (mna of $454.6 \mathrm{~g}$ ). The reverse is blank. Find place and date: Bolayır, 2013.

10) Private coll. (HK 003).

Tritemorion/triton (Fig. 10)

This is a lead weight, square in form with slightly

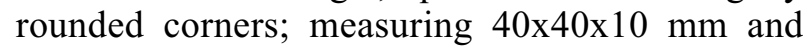
weighs $159.4 \mathrm{~g}$; worn. On the obverse is a lion protome jumping right; on the top left and right corners, $\Lambda-Y$; below the leg of the lion, $\Gamma(=3)$ which stands for tritemorion, i.e. one-third of a mna (mna of $478.2 \mathrm{~g}$ ); all in relief. Otherwise the $\Gamma$ may be a damaged $\mathrm{T}$, then again it stands for tritemorion or triton; but it looks like a gamma rather than a tau since it has no top left bar; all in relief. The reverse of the weight is blank. This weight was acquired in Malkara in 2000s.

11) Private coll. (Eskinazi, $\left.\mathrm{n}^{\circ} 17\right)$.

Tetarton (Fig. 11)

A lead weight, square in form with rounded corners; measuring $36 \times 34 \times 10 \mathrm{~mm}$ and weighing $122.51 \mathrm{~g}$; a small depression on left corner; worn. On the obverse is a lion protome jumping right; on the top left and right corners, $\Lambda-Y$ whose both letters are hardly discernible; all in relief. Despite the lack of denomination mark its mass corresponds to a tetarton, i.e. $1 / 4$ mna (mna of $490.04 \mathrm{~g}$ ). The reverse of the weight is blank. The weight was acquired in Selçuk, 2008.

12) Karadeniz Ereğli Museum (inv. nº 1989/27). Tetarton (Fig. 12)

A lead weight, square in form with rounded corners; measuring $37 \times 37 \times 9 \mathrm{~mm}$ and weighs $120.86 \mathrm{~g}$; worn. On the obverse is a lion protome jumping right, head turned back; on the corners, beginning from the top left $\Lambda-\mathrm{Y}-\Sigma-\mathrm{I}$ but $\Sigma$ is hardly visible; below the belly of the lion is $\mathrm{T}+\mathrm{E}$ (ligature) which stands for $\tau \varepsilon ́ \tau \alpha \rho \tau o v$; all in relief. It is a tetarton, i.e. $1 / 4$ mna (mna of $483.44 \mathrm{~g}$ ). The reverse of the weight is blank. Bought in 1989; find place uncertain.

13) Tekirdağ Museum (inv. $n^{\circ} B$, tentative). Tetarton (Fig. 13)

A lead weight, square in form with rounded corners; measuring $35 \times 35 \times 10 \mathrm{~mm}$ and weighs $120.10 \mathrm{~g}$; worn. On the obverse is a lion protome jumping right; on the top left and right corners, $\Lambda-Y$ but $Y$ is hardly visible; all in relief. Despite the lack of denomination mark its mass corresponds to a tetarton, i.e. 1/4 mna (mna of $480.4 \mathrm{~g}$ ). The reverse of the weight is blank. Find place and date: Bolayır, 2013.

14) Tekirdağ Museum (inv. $n^{\circ} 6$, tentative). Tetarton (Fig. 14)

A lead weight, square in form with rounded corners and a projection (tab) on the bottom left corner, worn. It measures $40 \times 41 \times 8 \mathrm{~mm}$ and weighs $118 \mathrm{~g}$. On the obverse is a lion protome jumping right, in relief; $\Lambda-Y-\Sigma-\mathrm{I}$ on the corners. Below the belly of the lion, $\mathrm{T}$ which stands for $\tau \dot{\varepsilon} \tau \alpha \rho \tau$ ov (mna of $472 \mathrm{~g}$ ); all in relief. The reverse is blank. Find place and date: Bolayır, 2013.

15) Tekirdağ Museum (inv. $n^{\circ} 17$, tentative).

Tetarton (Fig. 15)

A lead weight, square in form with rounded corners and a projection (tab) on the bottom left corner, worn. It measures $35 \times 35 \times 10 \mathrm{~mm}$ and weighs $113.35 \mathrm{~g}$. On the obverse, in relief, is a lion protome jumping right; $\Lambda-\mathrm{Y}-[\Sigma-\mathrm{I}]$ on the corners. Below the belly of the lion, TE (ligature) which stands for $\tau \varepsilon ́ \tau \alpha \rho \tau o v$ (mna of $453.4 \mathrm{~g}$ ); all in relief. The reverse is blank. Find place and date: Bolayır, 2013.

16) Private coll. (HK 004).

Hektemorion (Fig. 16)

A lead weight, square in form with rounded corners; measuring $35 \times 32 \times 8 \mathrm{~mm}$ and weighs $83.9 \mathrm{~g}$; worn. On the obverse is a lion protome jumping right; on the top left and right corners, $\Lambda-[\mathrm{Y}]$ but $\mathrm{Y}$ is hardly visible; all in relief. Despite the lack of denomination mark its mass corresponds to a hektemorion, i.e. 1/6 of mna (mna of $503.4 \mathrm{~g}$ ). The reverse of the weight is blank. This weight was acquired in Malkara in 2000s.

$$
* * *
$$

$\mathrm{N}^{\circ} 1$ is the largest unit of the known Lysimachean weights; although it does not bear any unit mark (or illegible since it is worn) its mass corresponds to a trimnaion. When we divide its mass to three, we get $c a .467 \mathrm{~g}$; this figure is a little bit under the standard Lysimachean mna of $c a .500 \mathrm{~g}$. But it is certain that $\mathrm{n}^{\text {os }} 2,3$ and 4 are mnas since they bear a unit mark (M) or their masses correspond to their units $(509 \mathrm{~g}$, $502.9 \mathrm{~g}, 501.4 \mathrm{~g}$, respectively). The masses of the other mnas at hand are also near to these values 


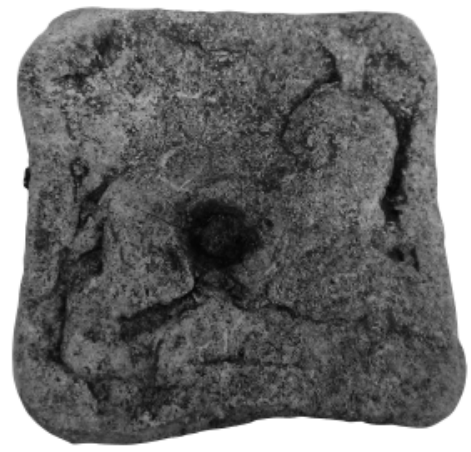

A

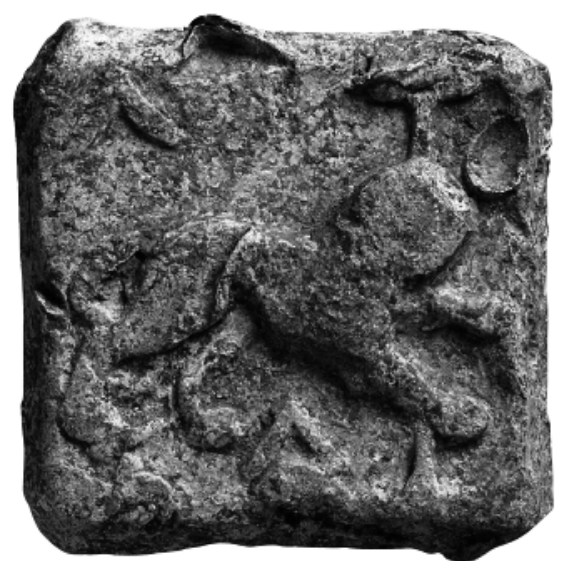

D

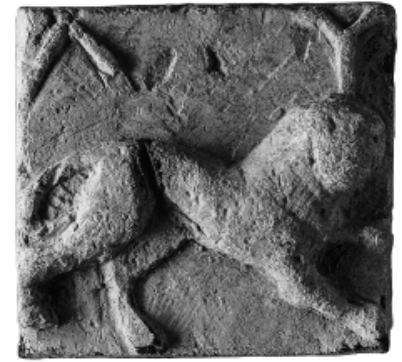

B

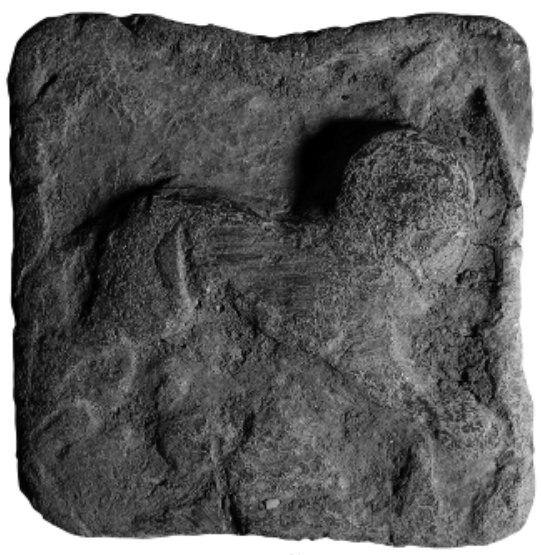

C

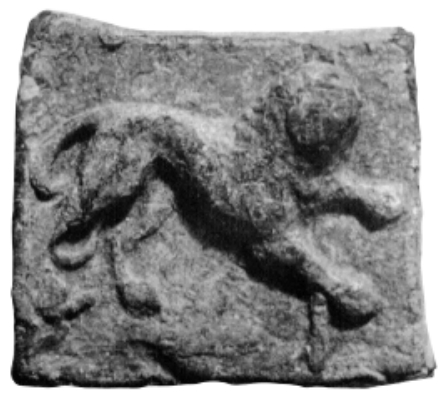

$\mathbf{F}$

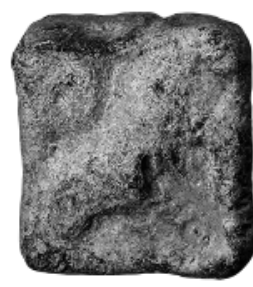

$\mathbf{J}$

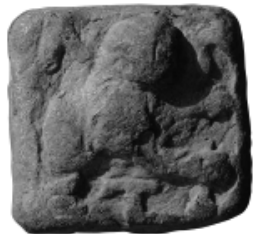

$\mathbf{N}$

A. CPAI Turkey 2: 21; B. CPAI Turkey 3: 2; C. CPAI Turkey 2: 22; D. Gorny \& Mosch, 175: 323; E. Vassilev 1988: 1; F. Lang 1968: no. 3; G. Gorny \& Mosch, 169: 448; H. Tekin 2013b: 4.; I. Gorny \& Mosch, 175: 327; J. Canakkale Museum (6110); K. CNG 258: 20; L. CNG 217: 20; M. Efes Museum (56.5.10); N. Tekin 2013b: 5. 


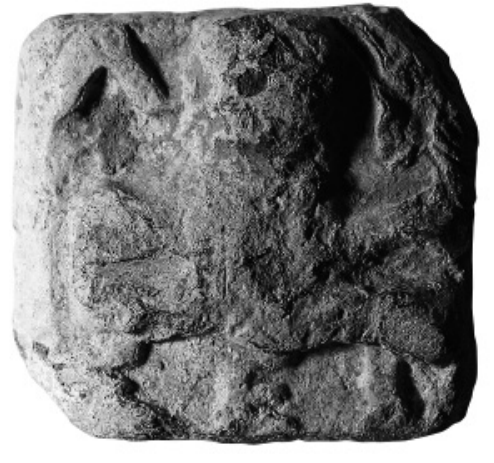

$\mathbf{O}$

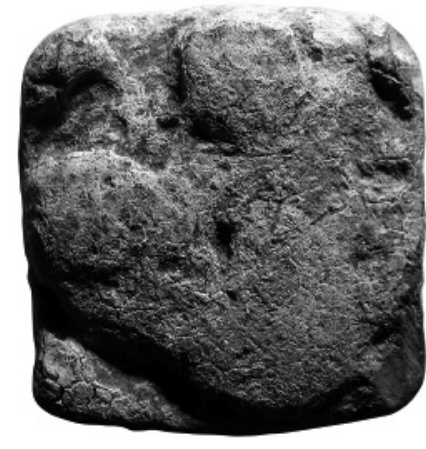

$\mathbf{P}$

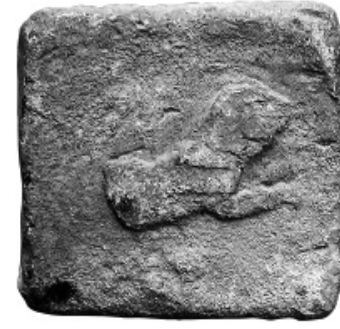

$\mathbf{R}$

\section{O. CPAI Turkey 2, 23; P. CPAI Turkey 2, 24; R. CPAI Turkey 3, 3.}

(Fig. A: 505 g $^{10}$; Fig. B: 496.80 g $^{11}$; Fig. C: 489.74 g $^{12}$ and Louvre example, $480 \mathrm{~g}^{13}$ ). Thus, from the extant examples, it is proven that the Lysimachean mna was about $500 \mathrm{~g}$. For example, while a dimnaion in an auction ${ }^{14}$ is $1000 \mathrm{~g}$ (Fig. D), another dimnaion in the National Archaeological Museum in Sofia ${ }^{15}$ is $897 \mathrm{~g}$ (Fig. E). In fact, the original mass of the Sofia weight was about $990 \mathrm{~g}$ since it has a loss of mass as Vassilev, the author, stated. Vassilev read the inscription on the weight in Sofia as $\Lambda(?) Y \Sigma M I$. But, first, I have to state that the letters $\Lambda$ and Y on the top left and right corners are clear; thus, it is unnecessary to give the lambda with a question mark. But the main problem is below the lion. There is no $\mathrm{M}$ there as Vassilev said. It reads either $\Sigma \mathrm{I}-\Delta \mathrm{I}$ or $\Sigma-\Delta-$ I. There are only two formulas on the Lysimachean weights, on which generally ethnic or unit mark occurs: either a letter on each corner, i.e. $\Lambda-\mathrm{Y}-\Sigma-\mathrm{I}$, or only $\Lambda-\mathrm{Y}$ on the top left and right corner ${ }^{16}$. If there is a unit mark, its place is in the field below the lion's belly or between the two letters on the bottom left and right corners. There is a long relief on the bottom left corner of the Sofia weight (to the right of sigma), if it is not a deformation, it may be an iota. If so, on this corner, we may expect the $\Sigma \mathrm{I}$ as a continuation of the $\Lambda-\mathrm{Y}$ on the top corners. The $\Delta \mathrm{I}$ after $\Sigma \mathrm{I}$ stands for the dimnaion. But, on the other hand, if the relief near the sigma on the bottom left corner is not an iota, i.e. if it is only a deformation on the piece, then the common formula will be the case, that is $\Lambda-Y-\Sigma-\mathrm{I}$ and a $\Delta$ which stands for a dimnaion. In any case, there have been no M on the Sofia weight as Vassilev had stated. Another point to be emphasized on the dimnaion and mna units of Lysimachea is that the lion is depicted as a full figure, not a protome. Because lion is depicted as a protome only on the fractions. The 'one and a half mna?' which was misattributed to Smyrna by Lang $^{17}$ (Fig. F) bears a full lion figure $^{18}$.

In the catalogue above there are five hemimnaion weights $\left(\mathrm{n}^{\text {os }} 5-9\right)$. Their masses are $248.2 \mathrm{~g}\left(\mathrm{n}^{\circ} 5\right)$, $248 \mathrm{~g}\left(\mathrm{n}^{\circ} 6\right) 241.2 \mathrm{~g}\left(\mathrm{n}^{\circ} 7\right), 232.5\left(\mathrm{n}^{\circ} 8\right)$ and $227.3 \mathrm{~g}$ $\left(n^{\circ} 9\right)$, respectively. While the first three indicate a mna of 490/500 g; the last two indicate a mna of $455 / 465 \mathrm{~g}$. The hemimnaion unit on the Lysimachean weights is clear not only from their masses, but also from the letter $\mathrm{H}$ below the belly of the lion, which stands for hemimnaion. The hemimnaion units of Lysimachea are also known from other collections (Fig. G: 249 g ${ }^{19}$; Fig. H: 246.43 g ${ }^{20}$; Fig. I: 207.89 g $^{21}$ and Berlin example, $246.30 \mathrm{~g}^{22}$ ). It is characteristic

10) CPAI Turkey 2: 21

11) CPAI Turkey 3: 2.

12) CPAI Turkey 2: 22

13) Louvre, Salle des bronzes, inv. no 1796: Ridder 1915: 166, pl. 115, no. 3318; Vassilev 1988: 8.

14) Gorny \& Mosch, 175: 323.

15) Vassilev 1988: 1. I would like to thank Evgeni Paunov who translated the article from Bulgarian to English for me.

16) $\Lambda \mathrm{Y}$ takes place on the bottom corners on a few weights; for example, CPAI Turkey 3: 3 (Fig. R).

17) Lang 1968: $\mathrm{n}^{\circ} 3$.

18) For its attribution to Lysimachea see Tekin 2013.

19) Gorny \& Mosch, 169: 448.

20) Tekin 2014: 4

21) Gorny \& Mosch, 175: 327.

22) Pernice 1904: $45, \mathrm{n}^{\circ} 7$. 
that the lion is depicted as protome instead of fullfigured on the hemimnaion units. But, as unusual, the lion on Fig. G, occurs full-figured. However, it is not possible to be sure that this is the case for the bronze weights since all the other weights are of lead ${ }^{23}$. In fact, another interesting point for the lion is its iconography. The lion on the Lysimachean weights is in the jumping position, either it is depicted full-figured or as protome ${ }^{24}$; but the lion on this bronze weight is similar to that depicted on the Cardian coinage: lion crouching left, breaking a spear held in its mouth (Fig. K) ${ }^{25}$. This shows us that the lion type on the Cardian coins was copied exactly on the Lysimachean weights. We know that the people of Cardia had been transferred to the newly founded Lysimachea after it was destroyed by Lysimachus. Thereafter, the Cardian coin types became the types of the Lysimachean coins and weights. The lion, which is looking back $\left(\mathrm{n}^{\text {os }} 5-9\right.$ and 13), is also familiar from the coins of Cardia (Fig. L) ${ }^{26}$. It can be proposed easily that the lion type was so important for Lysimachus and Lysimachea since it was used commonly on their coins as well as on the weights. The lion continued to be used on both coins and weights of Lysimachea as a civic badge (episemon/parasemon) for a long period (Fig. M) ${ }^{27}$.

$\mathrm{N}^{0} 10$ should be a tritemorion since it bears a $\Gamma$ $(=3)$; if it is not a gamma but a deformed tau, this would not change its unit since the both letters cor- respond to the same unit. The lion on this weight is depicted as a protome, which is suitable for its unit.

$\mathrm{N}^{\circ} 11(122.51 \mathrm{~g}), \mathrm{n}^{\circ} 12(120.86 \mathrm{~g}), \mathrm{n}^{\circ} 13$ $(120.10 \mathrm{~g}), \mathrm{n}^{\circ} 14(118 \mathrm{~g})$ and $\mathrm{n}^{\circ} 15(113.35 \mathrm{~g})$ are tetartons, i.e. 1/4 mnas, and their masses correspond to their units. Both on tetartons presented here and on the tetartons from the other collections (Fig. $\mathrm{N}^{28}$, $\left.\mathrm{O}^{29}, \mathrm{P}^{30}, \mathrm{R}^{31}\right)$, the lion is depicted as a protome again. Besides, while on the two examples ( ${ }^{\text {os }} 11$ and 13$)$ there is no unit mark, on three examples $\left(n^{\text {os }}\right.$ $12,15,14)$ there are TE and T, respectively, indicating tetarton. Similarly one of the two examples (Fig. N) bears $\mathrm{T}$ (tetarton), the other (Fig. O) bears TA (tartemorion). Lysimachean tetartons indicate that one $m n a$ is about $480 \mathrm{~g}$ although some have lower mass.

The smallest unit in the present catalogue $\left(\mathrm{n}^{\circ} 16\right)$ is a hektemorion of $83.9 \mathrm{~g}$. The lion is depicted as a protome like the previous fractions of mna. Although there is no unit mark on the weight as is common on the small units, its mass corresponds to a hektemorion ( $83.9 \mathrm{~g} \mathrm{x} 6=503.4 \mathrm{~g}$ ).

Lysimachean weights at hand indicate that the Lysimachean mna was about $500 \mathrm{~g}$ according to our metric calculations. The weights of Lysimachea, as mentioned above, date from between 309 B.C. when the city was founded by Lysimachus and the mid$2^{\text {nd }}$ century B.C. (or a little later) when it was destroyed by the Thracians ${ }^{32}$.

O.T.

23) There is an inscription on the weight punched later; it reads MA- $\Gamma$ or MA- $-\Gamma-I$.

24) On the obverse of a weight in Çanakkale Museum (inv. $n^{\circ}$ 6110) there is an animal resembling a seated lion to right but it is not certain since it is too worn and its attribution to Lysimachea is doubtful as well (Fig. J). Its mass (64.7 g) corresponds to an ogdoon .

25) $C N G$ 258: 20.

26) $C N G$ 217: 20.

27) Efes Museum, inv. no 56.5.10.

28) Tekin 2014: 5.

29) CPAI Turkey 2: 23.

30) CPAI Turkey 2, 24 .

31) CPAI Turkey 3, 3.

32) The last date for some Lysimachean weights published previously by the present author was given as the first quarter of the $3^{\text {rd }}$ century B.C. but this date should be extended to the mid- $2^{\text {nd }}$ century B.C. 


\section{BIBLIOGRAPHY}

Brodersen, K., 1986: “Zur Lage von Lysimacheia”, in Kalcyk, H., Gullath, G. and Graeber, A. (eds.), Studien zur alten Geschichte, Siegfried Lauffer zum 70. Geburtstag am 4. August 1981, Rome: 67-85.

CNG: Classical Numismatic Group.

CPAI Turkey 2: Corpus Ponderum Antiquorum et Islamicorum. Turkey 2. Istanbul Archaeological Museums. Greek, Roman, Byzantine and Islamic Weights in the Department of Metal Objects (by O. Tekin and G. BaranÇelik), Turkish Institute of Archaeology, İstanbul, 2013.

CPAI Turkey 3: Corpus Ponderum Antiquorum et Islamicorum. Turkey 3. Suna and Inan Klraç Foundation Collection at the Pera Museum. Greek and Roman, Weights (by O. Tekin), Suna and İnan Kıraç Foundation, İstanbul, 2013.

Gorny \& Mosch: Gorny \& Mosch. Giessener Münzhandlung GmbH-München.

Lang, M., 1968: "Five Hellenistic Lead Weights", ANSMuseum Notes 14: 1-3.

Lund, H.S., 1992: Lysimachus. A Study in Early Hellenistic Kingship, London.

Pernice, E., 1904: "Erwerbungen der Antikensammlungen in Deutschland. Berlin", Archäologischer Anzeiger XI, (Jahrbuch des Kaiserlichen Deutschen Archäologischen Instituts): 17-46.
Picard, Ch. and Reinach, A.J., 1912: "Voyage dans la Chersonèse et aux îles de la mer de Thrace", $B C H$ 36: 275-352.

Ridder, A. de, 1915: Les bronzes antiques du Louvre, II, Paris.

Sayar, M.H., 2007: "Zur Lage von Lysimacheia: eine hellenistische Hauptstadt auf der thrakischen Chersonesos", Proceedings of the $10^{\text {th }}$ International Congress of Thracology, Komotini-Alexandroupolis 18-23 October 2005, Athens: 514-517.

Tekin, O., 2013: "Calchedon and Lysimachia: Remarks on Two Published Hellenistic Weights", in Tekocak, M. (ed.), K. Levent Zoroğlu'na Armağan / Studies in Honour of K. Levent Zoroğlu, Antalya: 705-706.

- 2014: "Some Hellenistic Weights in the Çanakkale Museum", in Özfirat, A. (ed.), Scripta: Veli Sevin'e Armağan. Arkeolojiyle Geçen Bir Zaman Için Yazllar. I Scripta: Essays in Honour of Veli Sevin. A Life Immersed in Archaeology, İstanbul: 375-380.

Tzvetkova, J., 2009: "The Coinage of Kardia", Archaeologia Bulgarica XIII/1: 33-54.

Vassilev, V. P., 1988: “Оловна тежест на Лизимахия (Poids en plomb de Lysimachie)", Numizmatika (Sofia) 20/1: 7-8. 


\section{A COMPILATION OF THE LYSIMACHEAN WEIGHTS}

$\begin{array}{lll} & \text { Unit } \\ \text { Metal Mass Symbol Ethnic } & \text { Mark/ Reference } \\ \text { Name }\end{array}$

\section{TRIMNAION}

Lead $1400 \mathrm{~g} \quad$ Lion

$$
\begin{array}{ll}
{[\Lambda-Y-\Sigma-I](\mu \alpha \chi \varepsilon \dot{\omega} v)} & \begin{array}{l}
\text { no or not } \\
\text { visible? }
\end{array}
\end{array}
$$

\section{DIMNAION}

$\begin{array}{lll}\text { Lead } & 1000 \mathrm{~g} & \text { Lion } \\ \text { Lead } & 897 \mathrm{~g} & \text { Lion }\end{array}$

ONE AND A HALF MNA

$\begin{array}{lll}\text { Lead } & 653 \mathrm{~g} & \text { Lion } \\ & & \\ \text { MNA } & & \\ \text { Lead } & 509 \mathrm{~g} & \text { Lion } \\ \text { Lead } & 505 \mathrm{~g} & \text { Lion } \\ \text { Lead } & 502.9 \mathrm{~g} & \text { Lion } \\ \text { Lead } & 501.4 \mathrm{~g} & \text { Lion } \\ \text { Lead } & 496.80 \mathrm{~g} & \text { Lion } \\ \text { Lead } & 489.74 \mathrm{~g} & \text { Lion } \\ \text { Lead } & 480 \mathrm{~g} & \text { Lion } \\ \text { Lead } & - & \text { Lion }\end{array}$

\section{HEMIMNAION}

$\Lambda-\mathrm{Y}-\Sigma-\mathrm{I}(\mu \alpha \chi \varepsilon \omega \dot{v})$

$\Lambda-Y-\Sigma I(\mu \alpha \chi \varepsilon \dot{v} v)$

$\Delta$

$\Delta \mathrm{I}$

Gorny \& Mosch Giessener, 175, \#323 [Fig. D] Vassiliev 1988, fig. 1 [Fig. E]

$\Lambda-\mathrm{Y}-\Sigma-\mathrm{I}(\mu \alpha \chi \varepsilon \dot{v} v)$

- $\quad$ Lang 1968, fig. 3 [Fig. F]

$-$

$\Lambda-Y-\Sigma-I(\mu \alpha \chi \varepsilon \omega ́ v)$

$\Lambda-Y-\Sigma-\mathrm{I}(\mu \alpha \chi \varepsilon \dot{\omega})$

$\Lambda-\mathrm{Y}-\Sigma-\mathrm{I}(\mu \alpha \chi \varepsilon \dot{\omega} \mathrm{)})$

$\Lambda-\mathrm{Y}(\sigma \mu \alpha \chi \varepsilon \omega v)$

$\Lambda-Y-\Sigma-\mathrm{I}(\mu \alpha \chi \varepsilon \dot{v} v)$

$\Lambda-Y-\Sigma-\mathrm{I}(\mu \alpha \chi \varepsilon \dot{\omega} v)$

$\Lambda-Y-\Sigma-\mathrm{I}(\mu \alpha \chi \varepsilon \omega \dot{v})$

$\begin{array}{lll}\text { Bronze } & 249 \mathrm{~g} & \text { Lion } \\ \text { Lead } & 248.2 \mathrm{~g} & \text { Lion's protome } \\ \text { Lead } & 248 \mathrm{~g} & \text { Lion's protome } \\ \text { Lead } & 246.43 \mathrm{~g} & \text { Lion's protome } \\ \text { Lead } & 246.30 \mathrm{~g} & \text { Lion's protome } \\ \text { Lead } & 241.2 \mathrm{~g} & \text { Lion's protome } \\ \text { Lead } & 232.5 \mathrm{~g} & \text { Lion's protome } \\ \text { Lead } & 227.3 \mathrm{~g} & \text { Lion's protome } \\ \text { Lead } & 207.89 \mathrm{~g} & \text { Lion's protome }\end{array}$

\section{TRITEMORION/TRITON}

Lead $\quad 159.4 \mathrm{~g} \quad$ Lion's protome

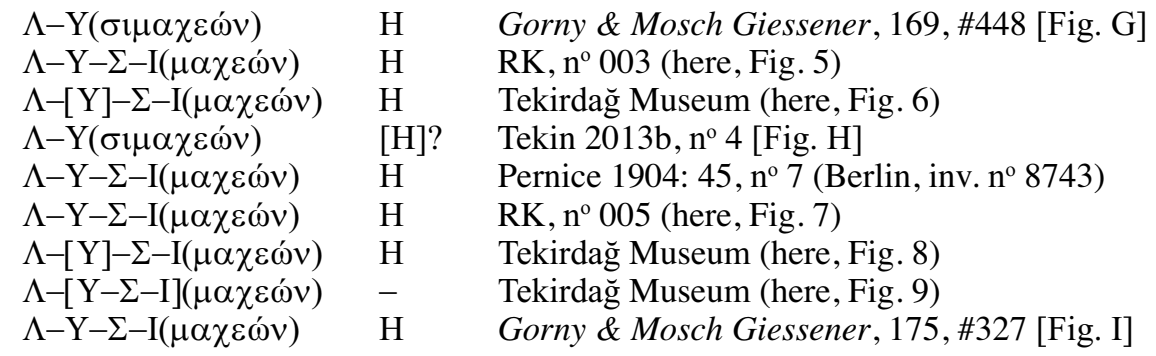

$\Lambda-\mathrm{Y}(\sigma \mu \alpha \chi \varepsilon \dot{\omega} v)$

$\Gamma\left(\right.$ or T) HK, $\mathrm{n}^{\circ} 003$ (here, Fig. 10)

\section{TETARTON}

$\begin{array}{ll}\text { Lead } & 122.51 \mathrm{~g} \\ \text { Lead } & 121.36 \mathrm{~g} \\ \text { Lead } & 121.09 \mathrm{~g} \\ \text { Lead } & 120.86 \mathrm{~g} \\ \text { Lead } & 120.10 \mathrm{~g} \\ \text { Lead } & 119.93 \mathrm{~g} \\ \text { Lead } & 118 \mathrm{~g} \\ \text { Lead } & 113.35 \mathrm{~g} \\ \text { Lead } & 109.85 \mathrm{~g}\end{array}$

Lion's protome

Lion's protome

Lion's protome

Lion's protome

Lion's protome

Lion's protome

Lion's protome

Lion's protome

Lion's protome

illegible or no $\Lambda-\mathrm{Y}-\Sigma-\mathrm{I}(\mu \alpha \chi \varepsilon \dot{\omega} v) \quad \mathrm{T}$ $\Lambda-Y-\Sigma-\mathrm{I}(\mu \alpha \chi \varepsilon \dot{\omega} \nu) \quad$ TA $\Lambda-Y-\Sigma-\mathrm{I}(\mu \alpha \chi \varepsilon \dot{\omega} \nu) \quad \mathrm{TE}$ $\Lambda[\mathrm{Y}-\Sigma-\mathrm{I}](\mu \alpha \chi \varepsilon \dot{v}) \quad-$ $\Lambda-Y[\Sigma-I](\mu \alpha \chi \varepsilon \dot{v})^{-} \quad-$ $\Lambda-Y-\Sigma-\mathrm{I}(\mu \alpha \chi \varepsilon \dot{v}) \quad \mathrm{T}$ $\Lambda-Y-[\Sigma-I](\mu \alpha \chi \varepsilon \omega \dot{v}) \quad \mathrm{TE}$ $\Lambda-\mathrm{Y}(\sigma \mu \alpha \chi \varepsilon \dot{v})$

Eskinazi coll. (here, Fig. 11)

Tekin 2013b, $\mathrm{n}^{\circ} 5$ [Fig. N]

CPAI Turkey 2, $\mathrm{n}^{\circ} 23$ [Fig. O]

E Karadeniz Ereğli Museum (here, Fig. 12)

Tekirdağ Museum (here, Fig. 13)

CPAI Turkey 2, $\mathrm{n}^{\circ} 24$ [Fig. P]

Tekirdağ Museum (here, Fig. 14)

Tekirdağ Museum (here, Fig. 15)

CPAI Turkey 3, n 3 [Fig. R]

\section{HEKTEMORION}

Lead $83.9 \mathrm{~g}$ 



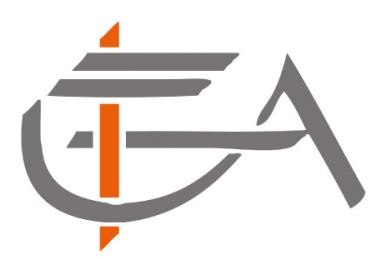

Institut Français

d'Etudes Anatoliennes

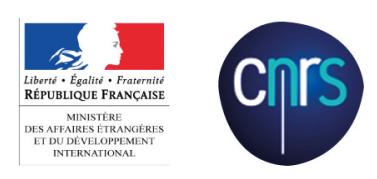

Peinture rupestre préhistorique, Sağlık Köy, près d'Alabanda, Turquie (cliché Suat Ateşlier). 